\title{
A Nietzschean Theory of Emotional Experience: Affect as Feeling Towards Value
}

\section{Jonathan Mitchell - forthcoming in Inquiry (final draft: please do not quote without}

permission)

\section{Introduction}

Despite recognition by commentators that emotions play an important role in Nietzsche's philosophy for example, in his critique of morality and philosophical psychology - the question of what an emotion is for him has not received detailed attention. ${ }^{1}$ This article corrects this by examining passages from Nietzsche's texts, making use of insights from contemporary philosophy of emotion along the way. However, my aim is not exclusively exegetical. I argue that a Nietzschean theory of emotional experience can be reconstructed which does not have a contemporary equivalent.

The Nietzschean theory of emotion centres on the following claim: emotional experiences exhibit a distinctive form of affective intentionality, insofar as they involve felt valenced attitudes towards the (apparent) evaluative properties of their objects. Emotional experiences are therefore feelings towards value. This interpretation explains how Nietzschean affects can have evaluative content without being constituted by cognitive states, as these feelings towards value are neither reducible to, nor to be theorized along the lines of, judgements, perceptions, or other mental states.

The discussion proceeds as follows. I provide textual evidence that emotions play a ubiquitous role in Nietzsche's philosophy, and address worries about the project (section 1). I go on to examine Nietzsche's relation to basic features of emotions, such as their phenomenology and intentionality (section 2). I then argue that Nietzsche holds that emotional experiences can have evaluative content (section 3). Finally, section 4 reconstructs a Nietzschean theory of emotional experiences as feelings towards value.

\footnotetext{
${ }^{1}$ Commentators who emphasize emotions are Leiter 2013: 237-258, 2015; Janaway 2007, and more reservedly Katsafanas 2016: Ch.5. Poellner 2007: 227-261 and 2012: 52-80, discusses Nietzschean affects at length, attributing to him a perceptual view of emotions (see section 4).
} 


\section{The Ubiquity of Emotion and Three Problems}

Emotions play a ubiquitous role in Nietzsche's philosophy. Consider his claim that contemporary morality originates from a specific type of vengeful hatred (ressentiment) and that 'noble morality' which historically precedes 'slave morality' - is formed out of what he calls a 'pathos [passion] of distance...the continuing and predominant feeling [Grundgefühl] of complete and fundamental superiority of a higher ruling kind in relation to a lower kind...that is the origin of the antithesis 'good' and 'bad" (GM I 2). ${ }^{2}$ Furthermore, he writes 'morality is just a sign language of the affects [Affekte] (BGE 187), and gives affects a central place in his philosophical psychology - his specification of the most fundamental components of human nature (see BGE 23, 12; KSA 13:[2]13). ${ }^{3}$

Nietzsche also claims certain emotions are instrumentally useful for cultivating, his higher type of person, ${ }^{4}$ asserting that the 'affect of a tremendous dread' could make possible someone who exemplified 'tremendous self-conquering' (WLN 5[61]). ${ }^{5}$ However, he does not recommend emotionality per se, claiming that achieving an evaluative perspective beyond the religious-moral norms and values constitutive of Judeo-Christian morality involves freeing 'oneself from the old emotional impulses of traditional values' (WLN 15[117]).

These passages show emotions playing a central role in Nietzsche's philosophy. Yet, the import of these ideas can hardly be fully appreciated without some conception of what an emotion is for him. For example, if Nietzsche's appeal to emotions in explanations of why we make value judgements (specifically moral ones) is to debunk the (putative) objectivity and normative authority of those judgements, that might only follow given a specific conception. Namely, of emotions as worldindependent, non-representational Humean sentiments, where their evaluative nature is specifiable at the personal level without reference to evaluative features, as features of the objects of those states. Yet,

\footnotetext{
${ }^{2}$ See Bibliography for translations of Nietzsche's texts as used here. Translations from Nietzsche's KSA are my own.

${ }^{3}$ Nietzsche also ascribes a role to affects in his accounts of other mental phenomena (e.g. willing, see BGE 19, and thinking, see GM III 12).

${ }^{4}$ See Leiter 2015: 23, 89, 103, 238, on Nietzsche's higher types.

${ }^{5}$ See also A7, WLN 5[34], WP 98, 196, 931.
} 
there are alternatives to this view, and we would need more textual evidence than has been provided for it. $^{6}$

However, there are barriers to a better understanding of what an emotion is for Nietzsche. The first is terminological: Nietzsche prefers the German term Affekt $[e]$ to Emotion in contexts where he is discussing emotions (e.g. pity, love, contempt; see BGE 23 ). ${ }^{7}$ In certain circumstances this is not a problem, since it is clear Nietzsche construes affects as emotions, as when he talks of the 'Yes-saying affects', and lists pride, joy, gratitude, and reverence, which are all familiar emotions (WLN 14[11]). Yet his use of Affekt[e] is sometimes broader, extending to 'the will and capacity to command' (WP 98), which is a character trait, and 'irascibility' and 'arrogance' (BGE 260), which are affective dispositions. In what follows I take many of Nietzsche's discussions of affects as referring to occurrent, conscious, emotional experiences (the motivation for this is explained below), however it should be kept in mind that the term has broader extension.

The second problem is methodological: there are few passages where emotions are the object of theoretical reflection. While Nietzsche often discusses specific emotions, arguably he has no worked out view about the nature of emotions, and therefore we risk anachronism by attributing him one. Such a conclusion, however, does not square with the role affects are given in his philosophical psychology, as essential to explaining the sources of a range of evaluative phenomena (see BGE 187). If Nietzsche intends affect to be a central psychological-evaluative notion (see BGE 23), then we need an account of what an affect is. Moreover, many of Nietzsche's first-order evaluations are framed in terms of descriptions or expressions of occurrent emotional responses to specific phenomena - for example, his disgust at the 'men of ressentiment', and revulsion at the cross. ${ }^{8}$ So, we can also reconstruct a

\footnotetext{
${ }^{6}$ See Leiter 2015: 8, and Prinz 2007: Ch.4 and Ch.7. Leiter argues that Nietzsche's view of affects is noncognitivist, such that the basic affective feel can typically be type-identified without reference to cognitive content (Leiter 2013: 242-43, see sections 2, 3 and 4 for discussion).

${ }^{7}$ See also HA I 42, WP 388. The German term Emotion, only occurs 6 times in the published corpus (HA I 103, 108, 138, 140, HA II 324, GM III 15). Across all translations, the term Affekt[e] is occasionally translated as emotion, but overwhelmingly as affect.

${ }^{8}$ Respectively see GM I 14, WLN 10[181], and CW, 1-12.
} 
Nietzschean view of emotions by reflecting on the role emotions play in his first-order evaluative practices. ${ }^{9}$

The third problem is that taking occurrent emotional experiences as the main focus of inquiry may overlook Nietzsche's claim that conscious phenomena are superficial, and that conscious experiences are distorting (see GS 354, 11; A 39). What to make of such claims is complicated, ${ }^{10}$ yet a number of points with respect to my project need bearing in mind.

First, one can provide a theory of occurrent conscious emotional experiences - indeed I show Nietzsche (at times) expresses such an adumbrated theory - while thinking that many such experiences are in some sense 'superficial' or 'distorting' (GS 354). Perhaps they are 'distorting' by failing to be veridical (e.g. failing to meet the correctness conditions set by their content), or involve forms of selfdeception (section 3.2 discusses one such case).

Second, in the central passage where Nietzsche questions the explanatory role of consciousness, he says 'all of life would be possible without, as it were, seeing itself in a mirror...the predominant part of our lives actually unfolds without this mirroring - of course including our thinking, willing, and feeling lives' (GS 354). On one reading, he is questioning the idea, also criticized by Gilbert Ryle, that mental content is self-luminescent. ${ }^{11}$ In other words, that in 'thinking, willing, and feeling' I am not just aware of whatever object I am x-ing about, but I am synchronously aware of myself being aware of that object. Nietzsche could criticize this HOT notion of consciousness, as one which necessarily includes a copresent higher level cognitive self-awareness, while consistently accepting the explanatory importance of pre or non-reflective occurrent experiences, which do not include such self-luminance. Emotional experiences are plausibly pre-reflective in this sense, in that they do not paradigmatically involve the co-present cognitive self-awareness Nietzsche finds 'superfluous' and distorting (GS 354). ${ }^{12}$ Reflecting

\footnotetext{
${ }^{9}$ See Poellner 2012: 52-80. NB: The theory articulated in section 4, while based on passages from Nietzsche, is Nietzschean - it is a reconstruction from specific passages.

${ }^{10}$ See Katsafanas 2016: chap 2 \& 3; Riccardi 2018: 93-112.

${ }^{11}$ Ryle 1990: 152-53.

${ }^{12}$ See Marcel and Lambie 2002: 219-259. See Riccardi 2018: 93-112, for a discussion of Nietzsche viz. HOT theories of consciousness.
} 
this, my use of the term 'conscious' in the rest of the paper refers to such pre-reflective experiences with phenomenal character, not to 'consciousness' in the higher-order cognition sense, or what we might call consciousness in the pejorative sense for Nietzsche.

Let me finally note the following consideration: the focus of contemporary emotion theory on occurrent, conscious, emotional experiences reflects the assumption that more complex affective states are often only fully intelligible by reference to occurrent emotional experiences. ${ }^{13}$ For example, the ressentiment Nietzsche describes as typical of the proponents of 'slave morality' is a complex emotional state of long duration, with characteristic patterns of expression and aims. ${ }^{14}$ Yet, ascribing this emotional disposition to someone is arguably only fully intelligible given that they have experienced an occurrent emotion of vengeful hatred towards another person and their qualities - indeed Nietzsche claims that emotions, specifically hatred and contempt, are the 'primum mobile' (the first and most important movers) in 'all the ideals of ressentiment' (WLN 10[9]).

So, to understand what an emotion is for Nietzsche, occurrent emotional experiences are one plausible starting place. This does not imply that he has nothing to say about other states in the affective domain, such as affective dispositions, unconscious emotions, or moods (or the relations between these states and occurrent emotional experiences). Rather, it reflects the plausible assumption that he may have a view worth considering on the nature of emotions, couched at the level of emotional experiences.

\section{Basic features of emotions}

One basic feature of emotion, which many theories emphasize, is that there is something it feels like to be angry, happy, and disgusted - occurrent emotional experiences have a felt phenomenology. This is reflected in folk talk of feelings of anger, happiness, and disgust, a nomenclature Nietzsche uses, talking of the 'feeling of fear (D 9), the 'feeling of pity' (BGE 30), and the 'feeling of perfection' (A 56). In line with Nietzsche's worries about reflective consciousness, the 'of' here is not that of intentionality but of specification. In 'feelings of pity', pity is not (or at least need not be) the intentional object of a

\footnotetext{
${ }^{13}$ See Deonna and Teroni 2009: 359-77.

${ }^{14}$ See GM I 10-15.
} 
higher-order mental state, but rather the 'of' specifies the type of experience a subject is enjoying. Nietzsche also talks of affects as felt, writing that the 'noble type' experiences 'a sense of indignation that one man should fare badly beneath his dignity and equal rights...these affects are felt by nobler natures (HA II 'Wanderer and His Shadow' 29). Nietzsche is therefore cognizant of emotional experiences as having an occurrent phenomenology.

However, without a precise specification of the phenomenal character of emotion the above claims are not particularly informative. Feeling theories specify this phenomenal character in terms of a pleasant or unpleasant (hedonic) feeling, akin to a sensation. Further, they claim that the emotion just is this sensation (e.g. the relevantly valenced 'pangs'), although it is typically accompanied by an idea of its cause. For example, Spinoza - whose view of affects Nietzsche was familiar with (see BGE 198) - thinks of love as a feeling of pleasure accompanied by the idea of its cause. ${ }^{15}$ In certain passages Nietzsche specifies the phenomenal character of affects more narrowly in somatic terms. He talks of the affects which 'create bile or raise the blood temperature' (A 20), and claims that 'every inner movement (feeling, thought, affect) is accompanied by vascular changes and consequently by changes in colour, temperature and secretion' (WP 811; see also WP 864, KSA 5:4[218]). Given this emphasis on the body (a frequent concern of Nietzsche's), it is helpful to say more about somatic feeling theories.

Somatic feeling theories specify emotions in terms of an interoceptive conscious registering (an 'inner perception') of somatic states, as awareness of the physiological condition of the body. Anger, for example, is specified in terms of a range of felt bodily changes, including increased heart rate, muscle tensing, characteristic grimace, and increased blood flow, which happen as the result of excitation (what James calls the 'exciting fact'). According to these theories, an emotion is the physiological changes experienced ('perceived') when undergoing it - this occurrent feeling of the relevant physiological changes is the emotion (as James puts it). ${ }^{16}$ So, given Nietzsche's emphasis on the somatic dimensions of affects should we attribute a similar feeling theory to him?

\footnotetext{
${ }^{15}$ Similar feeling theories are found in Descartes 1989: Part I and Hume 1978: II.1.1.276.

16 See James 1884: 188-205 and Lange 1885, 675 (cf. Barlassina and Newen 2014, for an 'impure' somatic feeling view). Note one might think that Nietzsche could hold a somatic view of the emotions but which was not a feeling theory. Given my interest in conscious emotional experiences the relevant view for consideration has to
} 
Note, many emotional experiences include somatic states, especially the 'hot' ones (e.g. anger, fear) - the phenomenology and empirical psychology confirms as much. So, one position suggested by the above passages is that Nietzsche thinks emotions typically involve somatic states as accompaniments. This position needs distinguishing from the stronger view that emotions just are interoceptive states, as awareness of these somatic states. In fact, Nietzsche's claims that the relevant somatic states are consequences of the affect (WP 811), or are 'created' (i.e. caused) by it (A 20) - such that the direction of causal influence is from affect to somatic state - are at odds with the somatic feeling theory, which sees changes in bodily states as causally prior to, or partially constitutive of, the emotion (and awareness thereof as what emotions are). So, there is some textual evidence that Nietzsche does not subscribe to key aspects of a somatic feeling theory (at least in its standard Jamesian guise).

However, the interpretative issues are arguably more complex than suggested above. Note that to fully refute the feeling theory reading, we would require that the emotion, whatever it is, be separate from, and either co-occurrent with or causally responsible for, the bodily changes and their perception. Both passages cited can certainly be read as suggesting that. However, arguably they could also be read as claiming that emotions involve bodily changes, without specifying the nature of this involvement. Perhaps vascular changes 'accompany' emotions because emotional feelings are in fact bodily feelings. Also, we might think that even if Nietzsche were claiming that affects cause vascular changes, etc., strictly this says nothing on whether the affect in question is, itself, a state of bodily feeling - it would only speak to a possible causal role for such states. These are complex issues. Here it suffices to note that on one plausible reading of these passages there is a tension between what Nietzsche claims and the strictures of a somatic feeling theory, although more needs to be said.

Although perhaps not an explicit concern of Nietzsche's, it is preferable that he does not think of emotions as (awareness of) physiological changes, since it is unclear how the somatic feeling theory (much less hedonic feeling theories) can overcome individuation problems. ${ }^{17}$ Bodily feelings are

be a feeling theory. Nonetheless, the following discussion leaves it open whether Nietzsche may nonetheless hold a somatic view of 'unconscious affects'.

${ }^{17}$ Nietzsche does talk of 'collecting material, formulating concepts, and putting into order the tremendous realm of tender value feelings and value distinctions', as preparation for a 'typology of morals' (see BGE 186). If 'value 
arguably insufficient to individuate emotions, as it is not clear there are distinct somatic states for all the different emotions. Note, there are two issues. (1) Does empirical psychology tell us that emotions can be individuated exclusively in terms of somatic states, and (2) can subjects, at least in favourable circumstances, differentiate their emotions in terms of felt bodily changes. With respect to (1), even if somatic type-identification is possible for 'basic' emotions (e.g. anger, disgust, fear, enjoyment, sadness and surprise $)^{18}$ - a claim for which the empirical psychology is inconclusive - the prospects for more complex emotions being type-identified in this way is poor. ${ }^{19}$ Regarding (2), arguably there are not qualitatively distinct somatic profiles for joy compared to happiness, or hate compared with anger, which are differentiable by their subjects in a sufficiently fine-grained way to allow for typeidentification exclusively in these terms. Moreover, if 'cool' emotions, such as admiration, reverence, or hope, can occur without awareness of felt physiological changes - such awareness being contingent rather than essential to them - type-identification of those emotions in somatic terms is not an option. ${ }^{20}$

Let me now take stock. Consideration of Nietzsche's relation to the somatic feeling theory raises important questions, answers to which call out for clarification of his view. First, if emotions are not just awareness of somatic states or hedonic feelings ('pangs' and 'throbs') then what else are they? Second, does Nietzsche take the felt component of emotions to be exhausted by their somatic, and or hedonic, aspects? He thinks typical occurrent emotions are felt, however the precise character of their phenomenology for him remains unspecified. Note, this is not an equivocation: one can accept emotions have a felt phenomenology while questioning whether that phenomenology is either best (or exhaustively) characterized in terms of somatic or hedonic states. I return to these issues in later sections, after specifying further basic features of emotions and Nietzsche's relation to them.

feelings' include emotional experiences (see section 3 and 4) then part of this project would involve typeindividuation of the relevant states.

${ }^{18}$ See Ekman 1999: 384-92.

${ }^{19}$ See Lindquist et al 2015: 121-143.

${ }^{20}$ See Stocker 2010: 401-423 and Poellner 2016: 13. James suggests non-standard emotions can occur without awareness of felt bodily changes (see James 1884: 191). 
Aside from having a felt phenomenology, contemporary emotion theorists regard typical emotions as intentional states, in at least the minimal sense that they are directed towards objects, such as physical particulars, persons or animals, events, and states of affairs involving these things. ${ }^{21}$ For example, in an episode of anger there is typically something I am angry about, such as the individual who just barged past me. Or in an episode of happiness there is typically something I am happy about, such as having passed my driving test. Emotion theorists label these things the particular objects of emotions. ${ }^{22}$ For example, the particular object of an episode of fear could be an Alsatian (animal); of anger, my boss (person); of despair, that Bill has been appointed Dean of the Faculty (state of affairs). By recognizing that emotions have particular objects we can capture a feature of their logical behaviour: the same emotion-type can be directed towards different particular objects (fear about $a, b, c$ etc.) and the same particular object can constitute (at least partly) the intentional content of different emotions (fear about $\mathrm{X}$, anger about $\mathrm{X}$, etc.). ${ }^{23}$

There is sufficient evidence that Nietzsche accepts that typical emotions are intentional states in this sense (see D 279, GS 14, GM II 16). For example, noble self-reverence takes the noble himself as its particular object (BGE 287) and the horror of the 'madman' has as its particular object the event of the death of God (GS 125, see also GS 343). Nietzsche also shows awareness of the logical behaviour of emotions, when he compares how a psychologist has 'profound pity and contempt' for the same particular objects, 'the very things', which 'the masses' have 'profound admiration' for (BGE 269).

Nevertheless, appreciating that emotions have a felt phenomenology (however specified) and particular objects, hardly amounts to much of a theory. We have no explanation of why particular objects are sometimes experienced as causing emotional experiences (and their phenomenology), rather than non-emotional intentional states targeting the same particular objects (call this the causal-

\footnotetext{
${ }^{21}$ Original feeling theories do not accept this, yet it is an objection that they overlook the way typical emotions have intentional objects, which may differ from their causes.

${ }^{22}$ See Lyons 1980: 104-6 and Teroni 2007: 395-415.

${ }^{23}$ I leave open how to characterize objectless emotions (e.g. free-floating anxiety) which may not have intentional objects - hence my claim that typical emotions are intentional states. However, when such 'objectless emotions' are conscious, they are likely as moods, which may be characterized as having a more general intentional content, rather than none (see Mitchell 2018: 118-134 for one such view).
} 
phenomenology problem). Moreover, we still face individuation problems: particular objects are insufficient to individuate emotions, since ex hypothesi different emotions can target the same particular object. That an emotion is about the death of God cannot tell us what emotion we are experiencing, and adverting to somatic accompaniments will not obviously help either, given the above criticism of somatic feeling theories (hedonic states ostensibly fare no better on this score). In what follows I consider the view that emotions have evaluative content, argue that Nietzsche accepts this for some emotional experiences, and then explain how this partially resolves these problems.

\section{Section 3. Nietzsche and the Evaluative Content of Emotions}

It is widely accepted in contemporary theory that there is more to emotions than can be captured by reference to particular objects and somatic states. One option is to stress the role of values. There is an etymological connection, as many of the evaluative predicates which figure in appraisals of particular objects, such as something being sad, disgusting, or joyous, match up with emotion-types. Relatedly, the values connected to emotions are typically determinate, such as the disgusting, fearsome, and admirable, rather than determinable, such as the good, bad, or (dis)valuable, and so are well-placed to play an individuating role. One way to theorize this evaluative connection is to claim emotions involve an evaluative appraisal of their particular objects. For example, admiration would involve an appraisal of its particular object as admirable. Note, such evaluative appraisals are part of the emotional experience, such that typical emotions involve them as a component, rather than their being prior evaluations to which emotions are reactions. ${ }^{24}$

Further specification of this evaluative aspect often leads to the claim that values figure in emotions as part of their intentional content, understood as evaluative properties which the particular objects of emotions are represented as possessing. For example, reverence does not just represent the noble (particular object), but represents the noble under the aspect of greatness. ${ }^{25}$ Moreover, evaluative

\footnotetext{
${ }^{24}$ See Teroni 2007: 408 (cf. Mulligan 2007: 1-24). This contrasts with some cognitive appraisal theories in psychology (see Lazarus 1991).

${ }^{25}$ My use of the term 'represent' here does not refer to strong representationalist views according to which what a mental state represents (its content) is determined by its causal-functional role as specified by an externalist
} 
properties, as figuring at the level of content, play a role in the correctness conditions specific to a given emotion. For example, given fear represents the fearsome, an emotion of fear with regard to $a$ will be, broadly speaking, correct just in case $a$ really is fearsome, and alternatively fear of $a$ will not be warranted if $a$ is not fearsome. So, we have the following claim: the content of a typical emotion is, at least in significant part, evaluative. ${ }^{26}$

Let me, however, note an important caveat. It might be thought the above view commits to idea that evaluative properties are monadic or 'simple' rather than relational. Yet surely an object can be (correctly)fearsome for one kind of creature but not another (e.g. a coyote is fearsome to a human infant but not to a fully-grown lion). However, we can distinguish between claims about the nature of evaluative properties and claims concerning how evaluative properties figure in emotional experiences. Many (perhaps all) evaluative properties are metaphysically relational, and so a complete assessment of emotions' correctness with respect to such properties would have to make reference to the subject as one of the relata. However, this leaves it open whether they are phenomenologically relational: whether evaluative properties figuring in the content of emotional experience are first-personally given by way of subject-reflexive qualifications, such that the relevant particular objects present as dangerous-for-me or beautiful-for-me. Reflection suggest that this is paradigmatically not the case. Consider a nature lover in awe of a stunning vista: the vista is presented as awesome such that the relevant evaluative property seems like a property the vista has in and of itself so to speak, rather than relative to my affectiveevaluative perspective. So, while theoretical reflection on evaluative properties may show those values to be relational in nature when emotion experientially presents its particular object under some evaluative aspect, there need be no (explicit) self-reference in the evaluative content of the experience. We can hold off on specifying the representational vehicle for this content (i.e. a judgement, perception,

psychosemantics (see Tye 1995). Rather the term is intended in the minimal intentionalist sense - what the relevant experience represents to its subject.

${ }^{26}$ This is accepted by evaluative judgement theories (Nussbaum 2001) and perceptual theories (Tappolet 2016: Ch.1; Döring 2007: 363-94). Deonna and Teroni locate to the evaluative dimension of emotions at the attitudinal level (Deonna and Teroni 2017: 55-63). 
or some sui generis state), because we need to examine whether Nietzsche accepts that emotions, at least sometimes, have evaluative content

Nietzsche talks of 'value feelings' (see BGE 4, 186, 211, WP 291, 994 1021), and characterizes 'negative emotional valuations' [Gefühls-Abwerthung] as 'value feelings' [Werthgefühl] (KSA 12:10[23]). One reading of Nietzsche's use of these phrases is that value feelings are emotional evaluations - further supported by his talk of 'tender value feelings' (BGE 186) - and so emotions, at least sometimes, have evaluative content. He also says 'the unreason or odd reason of passion is what the common type despises in the noble, especially when this passion is directed at objects whose value seem quite fantastic and arbitrary...the higher nature's taste is for exceptions' (GS 3, my emphases, see also WP 387). So, the noble's emotion is directed towards objects experienced as exceptional, and so represented as evaluatively qualified.

Further evidence is found for attributing to Nietzsche the view that emotions can have evaluative content in two more examples. It is worth emphasizing, we are trying to establish a phenomenological point about emotional experiences. We can bracket whether Nietzsche thinks in general, or in specific instances, the phenomenology is a reliable guide to the epistemology or metaphysics of value ${ }^{27}-$ apparent evaluative content is enough. Consider, Nietzsche's account of his experience of listening to Bizet:

Yesterday I heard Bizet's masterpiece for - would you believe it? - the twentieth time. Once again I waited with gentle devotion, once again I did not run away...This music seems perfect to me. It approaches lightly, supplely, politely. It is amiable, it does not sweat...I actually burn my ears under this music, I listen to its causes. It seems to me that I experience its origin - I tremble in the face of dangers that accompany some risk, I am charmed by strokes of luck that Bizet is innocent of. (CW 1)

\footnotetext{
${ }^{27}$ For further discussion see Leiter 2015: 126-51. One idea, expressed by Nietzsche in notebook passages (see WP 670, 804) is similar to the position of Angela Mendelovici. She thinks emotional experiences do represent sui generis evaluative properties, but since it is (apparently) implausible that anything possesses such properties - a claim about the metaphysics, rather than phenomenology, of value - then emotional experience involves 'figurative projectivism', whereby all emotional experience is non-veridical (see Mendelovici 2014: 135-57).
} 
It would be a fair account of Nietzsche's experience that Bizet's music (the particular object) is experienced as qualified by aesthetic perfection of a certain sort. While multifaceted, Nietzsche is describing an emotional experience of aesthetic admiration (of 'gentle devotion'), which involves a felt attraction towards the music, and is accompanied by a somatic state (trembling). ${ }^{28}$ Moreover, the expression 'seems perfect to me' highlights that Nietzsche is engaged in a description of his own affective experience, and at this level evaluative properties (aesthetic perfection) appear to qualify the music. A similar point is echoed when Nietzsche compares a 'feeling' he lived with, a 'passion', with 'courageous music which brings certain solace' (GS 317, italics mine).

Note, one can accept the above while holding that the non-evaluative properties of the music, its approaching 'lightly' - by which Nietzsche is likely referring to a conjunction of its tempo, melody, and timbre - constitute and make present (and so available to affective experience) the higher-order evaluative property of aesthetic perfection. Although the relation between the non-evaluative and evaluative properties is not theorized by Nietzsche, some form of supervenience, whereby values are higher-order properties dependent on conjunctive instantiations of lower-level properties, is a fair candidate; since if the melody or tempo were significantly altered, it would likely lose its quality of aesthetic perfection.

The next example is the affective experience of the ressentiment subject:

[E]very sufferer instinctively looks for a cause of his distress...more precisely for a guilty culprit who is receptive to distress... 'Someone or other must be to blame that I feel ill' - this kind of conclusion is peculiar to all sick people and in fact becomes more insistent, the more they remain in ignorance of the true reason, the physiological one, why they feel ill...'I suffer: someone or other must be guilty'...But his shepherd, the ascetic priest, says to him, 'Quite right, my sheep! Somebody must be to blame...you yourself alone are to blame for yourself'... That is bold enough, wrong enough: but at

\footnotetext{
${ }^{28} \mathrm{We}$ can remain non-committal on whether the relevant somatic accompaniments are experienced as caused by the evaluative representation, since this is controversial. See Prinz 2007: 56-60 against the idea that the evaluative representation causes the somatic aspects.
} 
least one thing has been achieved by it, the direction of ressentiment is, as I said - changed. (GM III

15)

Consider how the subject of ressentiment - the 'sufferer' who is in 'distress' - has his ressentiment redirected by the ascetic priest. At the start, he blames someone else for his suffering, 'the guilty culprit' - for the original slaves this is the nobles (GM I 13). Yet, the success of the ascetic priest's re-direction is premised on preserving the evaluative aspect of ressentiment, namely something's being blameworthy, but changing the particular object from an external object to oneself - that is to reflexive blame in the form of self-loathing. So, the logic of the story arguably presupposes that the evaluative dimension of the emotion is preserved, namely blameworthiness. Interestingly, Nietzsche identifies projective errors in the affective-evaluative phenomenology of ressentiment, both before the redirection and after it, claiming the real cause of the 'suffering' is physiological. Nevertheless, the emotion as experienced has (apparent) evaluative content. Whether there are emotions which make projective errors in their phenomenology of value, does not undermine the plausibility of this point. ${ }^{29}$

On the basis of this discussion we have good textual evidence that Nietzsche takes some emotional experiences to have (apparent) evaluative content. ${ }^{30}$

However, Brian Leiter writes - in criticism of this view - that 'we can agree...that affective experiences have intentional objects... without agreeing that such experiences 'represent these objects under value aspects': the death of a loved one may cause my grief - an affect which has as its object his death - but that does not mean my feeling 'represents' his death 'as sad': it just means that I feel sad about his death'. ${ }^{31}$ Aside from arguably misdescribing the emotional phenomenology, and its content, arguably such a view runs up against both the individuation and the causal phenomenology problems considered in section 2. Take grief as specified by Leiter. That an emotion is about a loved one's death (particular object) is not sufficient to individuate it as grief - one might respond with relief

\footnotetext{
${ }^{29}$ Identifying such projective errors may be central to Nietzsche's critique of the moral emotions, although I cannot pursue that point here (see WLN 1[22]).

${ }^{30}$ See also Poellner 2007: 227-61 and 2012: 52-80.

${ }^{31}$ Leiter 2014: 7-8.
} 
to the death of a loved one if they had been suffering for a long time. It could be responded that while the particular object is insufficient to individuate grief, that the 'feels sad' component will do. However, as discussed in section 2, if this component is specified somatically (or hedonically), then it is not clear it can do the necessary individuating work (and certainly not in all cases). It is arguably difficult to conceive of an episode of grief absent some awareness of a particular event or state of affairs as grievous. Moreover, without an evaluative representation of the death of a loved one as grievous it is harder to explain why that particular object (a specific state of affairs) causes grief in one instance, rather than a non-emotional judgement. ${ }^{32}$

Importantly, even if we accept, as Nietzsche sometimes claims, that 'anger, hatred, love, pity...joy and pain - are all names for extreme states' (D 115), this does not show that we don't nonetheless possess criteria for conscious individuation of differences between those 'extreme' states; we would still need a criterion for distinguishing anger and hatred, for example. In this sense, we should not confuse two claims: (1) that we either have, or can use, emotion concepts to fully express and individuate all our different affective-evaluative experiences - such that emotion concepts exhaustively cover the range of possible emotional experiences - something Nietzsche is rightly sceptical of (although cf. BGE 187), and (2) that there are categorical differences between emotion-types for which we should be able to point to the relevant criteria for individuation.

Represented (determinate) value properties of emotions' particular objects, are important for overcoming this individuation problem. Arguably part of the difference between being horrified at the death of God and being joyed by it is that the different emotions, while directed at the same particular object, represent it under a different evaluative aspect. Moreover, reference to represented value properties of emotions has the resources for a solution to the causal-phenomenology problem. Part of

\footnotetext{
${ }^{32}$ It is important to recognize that despite this disagreement with Leiter over the issue of whether emotions have evaluative content there is a significant agreement between his view of Nietzschean affects and the one developed in the following section. We both reject overly cognitive views which would see such affects as (at least in part) constituted by judgements, beliefs and desire, and perhaps also perceptions. Leiter also suggests understanding Nietzschean affects along the lines of 'feelings towards' ala Goldie (Leiter 2013: 243). The key difference is that the way my view specifies Nietzschean affects is as non-cognitive feelings towards values (see section 4).
} 
the explanation why Nietzsche's 'madman' experiences horror, and the felt phenomenology that comes with it, as caused by God's death, is that his emotion represents that particular object as horrific in a way that the factual belief that God is dead, or a different emotion concerning that state of affairs, does not. Nietzsche brings out this first contrast in his comparison between the 'madman' and those in the 'market-place', both of whom believe that God is dead, but the latter are not affected by it (GS 125), and the second contrast in a different passage where he describes those who feel cheerful or joyous at the 'death of God' (GS 343). Nonetheless, evaluative representation is not sufficient for the occurrence of an emotion, after all one can 'coldly', that is without affectivity, judge that the death of a loved one is sad. Yet, evaluative representation is arguably necessary for typical emotions: all instances of horror, for example, represent their particular objects as horrific. ${ }^{33}$

I now consider one candidate for the mental state which would possess the relevant evaluative content of emotional experiences which Nietzsche rejects, namely an evaluative judgement. Judgementalism claims emotions either are, or essentially involve, evaluative judgements. ${ }^{34}$ For example, fear essentially involves judging that its particular object is fearsome. This view encounters numerous problems, but one issue is the absence of emotional phenomenology. We can distinguish between a 'cold' evaluative judgement that something is fearsome and the 'hot' emotion of fear. However, if fear is essentially an evaluative judgement of the particular object of one's emotion as fearsome, then the distinctive phenomenology of emotions is either absent, or will need to be, in ad-hoc fashion, 'added on'. As we shall see in section 4, Nietzsche puts a distinctive phenomenological component at the forefront of emotional experience, so Judgementalism is a poor candidate for his view.

Moreover, such a theory is too intellectualistic to fit with what Nietzsche says about affects. For example, in a note, Nietzsche writes that 'the dangerousness of the Christian ideal lies in its value feelings [Werthgefühlen], in that which can do without conceptual expression' (WP 1021, see also D 34). One reading of what Nietzsche means by 'conceptual expression' is expression in paradigmatic conceptual states, such as beliefs and judgements; and 'value feelings', which plausibly include

\footnotetext{
${ }^{33}$ I explain the kind of evaluative representation particular to emotions in section 4.

${ }^{34}$ See Nussbaum 2001 (cf. Goldie 2000: Ch. 2).
} 
affective-evaluative states like emotional experiences, can (he claims) 'do without' such expression (i.e. they do not necessarily include such conceptual articulations). Note, one can hold that emotional experience does not essentially involve such conceptual articulations (i.e. evaluative judgements) while remaining non-committal on whether in general, or in specific instances emotional content is best thought of as conceptual or non-conceptual, since conceptual content is not plausibly co-extensive with the kind of linguistically expressible general concepts as they figure in judgements and beliefs. ${ }^{35}$

Additionally, Judgementalism is in tension with Nietzsche's claim that our evaluative judgements have their origins in our affects (see GS 335, BGE 187, WP 254, 714). If Nietzsche's point is that, in many cases, emotions explain both the origins of, and our continued adherence to, specific (in many cases moral) value judgements, then it would be odd if he thought of those affects as constituted by evaluative judgements, since there would be the judgement constitutive of the emotion and the judgement formed on its basis (so arguably one judgement too many). Rather, Nietzsche's appeal to affects to explain the aetiology of value judgements, such that affects are typically inputs to evaluative judgements, requires emotions and evaluative judgements being distinct. However, rejecting Judgementalism as characteristic of Nietzsche's view need not involve abandoning the claim that emotions sometimes have evaluative content; it is just that the representational component which possesses that content is not (for him) an evaluative judgement. The next step is to articulate what that representational component could be.

\section{A Nietzschean Affective Intentionality View}

I now provide a Nietzschean theory of emotion which makes (non-somatic) emotional phenomenology central. In this section I argue we can reconstruct a view of Nietzschean affects as involving something similar to the states which Peter Goldie calls feelings towards, which combine phenomenology and evaluative intentionality. ${ }^{36}$ So, this Nietzschean view, is a forerunner to affective intentionality views of emotions. ${ }^{37}$ However, the representational vehicle of the evaluative content is a sui generis mental

\footnotetext{
${ }^{35}$ Cf. Katsafanas 2016: Ch.1.

${ }^{36}$ See Goldie 2000: 58-61.

37 See Döring 2007: 363-94 and Johnston 2001: 181-214.
} 
component, not identifiable with perceptual, judgemental, imaginative, or other mental states. Indeed, as will emerge, this is one way of making sense of Nietzsche's references to 'value feelings' [Werthgefühlen] (see BGE 4, 186, 211, WP 291, 994 1021) - that is to a non-doxastic mental state in which evaluative appraisals are somehow inextricably tied to a distinctive phenomenology. In what follows I unpack this view.

To begin, here are further passages from Nietzsche:

Every ideal presupposes love and hatred, veneration and contempt. Either the positive feeling [positive Gefühl] is the primum mobile or the negative feeling [negative Gefühl] is. Hatred and contempt are, e.g., the primum mobile in all the ideals of ressentiment. (WLN 10[9])

[A] drive to something or away from something divorced from a feeling one is desiring the beneficial or avoiding the harmful, a drive without some kind of knowing evaluation of the worth of its objective, does not exist in man. (HA I 32)

The Yes-saying affects: pride, joy, the love of the sexes, reverence...gratitude towards earth and life.... everything that calls good, says Yes, does Yes. (WLN 14[11]).

The fire of love and the fire of anger glow in all the virtues...no greater power did Zarathustra find on earth than the works of those who love: their names are 'good' and 'evil' ( $\mathrm{Z}$ 'On a Thousand and One Goals')

When Nietzsche says that the 'positive' or 'negative' feeling is the primum mobile - the first and most important mover - in 'ideals' (i.e. values) he is highlighting a feature of the phenomenology of emotions that is different from, and cannot be parsed in terms of, non-intentional feelings or non-affective evaluative intentional content (or their conjunction). The first point to note is that this felt component is valenced, hence the reference to positive and negative feeling (WLN 10[9]). We also find this in the idea of the 'Yes-saying' affects, as they essentially have positive valence or 'affirmation', in contrast 
to 'Nay-saying' affects - like hatred and contempt - which essentially have negative valence or are characterized by 'denial' (WLN 14[11]), and in the contrasting valences of the 'fire of love' and 'fire of anger' ( $\mathrm{Z}$ 'On a Thousand and One Goals) ${ }^{38}$ So, in these emotional experiences, there is a felt favour or disfavor which is a constitutive part - what Nietzsche describes elsewhere as a 'Yes or No as reduced to a passionate wanting to-have or pushing away' (WLN 11 [71]). What though, more precisely, is this component that emotions putatively involve?

We are pointed toward thinking of this felt valenced component as directed outwards towards evaluative properties of the emotions' object, since Nietzsche describes how the feeling involves a 'knowing evaluation of the worth of its objective' (HA 1 32), and that the 'Yes-saying' affects involve a 'calling of good' (WLN 14[11]). So, these feelings of (dis)favour are intentional in an exteroceptive way, as directed at the particular object of one's emotion, evaluatively qualified. So, what-it-feels-like to experience a particular emotion is captured in terms of the way the particular objects of emotions feel to be a specific evaluative way through feelings of favour or disfavour. ${ }^{39}$

So, the passages from Nietzsche suggest a construal of emotional experiences as both felt, and having evaluative intentionality in a distinctive way. Here is the theoretical claim: the determinate value of the particular object is represented through a feeling of favour or disfavour. It would be in this way that phenomenology and evaluative intentionality are connected in emotional experience. However, this needs further unpacking.

Note, that this feeling of favour or disfavour, although representing the relevant value, is not a characteristic of the relevant object; felt valenced attitudes are not part of the content of emotions but are rather the vehicle for that content. In this sense, these felt valenced attitudes are carriers of evaluative content - it is in that sense that they involve an uptake of the (apparent) evaluative standing of the particular object of the emotion, or are potentially disclosures of value. ${ }^{40}$

However, can a felt component - in this case, a felt valenced attitude - be a representational vehicle for evaluative intentional content? To answer this question, note that admitting such feelings towards

\footnotetext{
${ }^{38}$ See also D 35 and WP 669.

${ }^{39}$ See Goldie 2000: 58-61 and Stocker 1983: 5-26.

40 See Poellner 2016: 13-4 and Montague 2009: 187-188.
} 
value into the class of mental states involves questioning the sharp distinction between the supposedly non-intentional felt components of emotions and their (again supposedly) non-affective evaluative intentional aspects. This distinction needs rejecting, especially when those aspects are (a) taken to exhaust the logical space of possibilities for what emotions include; and (b) the felt component is taken to be a mere feeling, i.e. a non-representational quale.

So, we can understand Nietzschean affects as exhibiting a distinctively emotional kind of affective intentionality: felt valenced attitudes represent the (apparent) value properties of their particular objects - as Nietzschean 'value feelings'. This is reflected in the passages in the following way. First, the 'saying yes' of the 'Yes-saying affects' can be made sense of since they involve, as part of their overall phenomenal character, a felt positive attitude towards their objects value: they 'call good', in that the feeling of favour is experienced as a disclosure of the evaluative standing of the particular object (WLN 14[11]). Likewise, a 'drive...away from something' involves an 'evaluation of the worth of its objective', in that it is 'avoiding the harmful', that is avoiding a particular object, evaluatively qualified - a value which is represented to the subject through that felt attitude of disfavour (HA I 32).

In this context, it makes sense for Nietzsche to describe 'positive' or 'negative' feelings as the 'primum mobile' in our ideals (WLN 10[9]; our values). Since those emotional experiences, as feelings towards value, would be our most basic, and at the pre-reflective level, cognitively unmediated, nondoxastic acquaintance with value. ${ }^{41}$ This point is reflected when Nietzsche claims that 'value feelings' [Werthgefühle] are 'different above and below' because for the lower types 'numerous experiences [zahllose Erfahrungen] are lacking' (KSA 8:9[16], see also GS 268), which leads to misunderstanding. Presumably the idea is that since the lower types have not affectively experienced a specific value as eliciting a feeling towards it they cannot fully understand it, or those who have had such experiences.

The temptation found in authors who think of emotions as involving this kind of affective intentionality has been to theorize such cases as perceptual experiences of value (i.e. the perceptual model of the emotions, on some versions of that view). Indeed, Peter Poellner attributes such a view of

\footnotetext{
${ }^{41}$ See also WP 387.
} 
affects to Nietzsche. ${ }^{42}$ However, we should resist thinking of the affective intentionality of those felt valenced attitudes as perceptions in any typical sense. So, when Nietzsche says 'value feelings' involve being able to 'gaze with many eyes' (BGE 221), and equates affects and 'eyes' (GM III 12), he is best understood as stressing the distinctively affective intentionality that affects possess; 'value feelings' provide one with a range of 'eyes' in the sense that affects represent a range of determinate values, rather than being strictly perceptual experiences of those values. Also, many of the affects which Nietzsche discusses involve imaginative capacities (like the slaves 'imaginary revenge' in GM I) and are somewhat indirect (like his affective-evaluation of Bizet's music) and so are not on any standard views, perceptions; they would be at best quasi-perceptual (see below for more on this).

However, if the motivation for the perceptualist view is merely to make emotions representations of value without making them judgements, then the Nietzschean theory could be read as one way of developing that thought. Nonetheless, typical perceptualist theories of emotion take on additional commitments not found in Nietzsche's writings, such as claiming that the rational role of emotional experience is analogous to that of perceptual experiences, and that the content of emotional experience has the same structure as sense-perceptual experience (e.g. non-conceptual). ${ }^{43}$

Furthermore, interpreted along sui generis lines, the Nietzschean view does not inherit objections to standard perceptualist theories. For example, it is not clear what the standard perceptualist should say about which aspect of the phenomenology of emotion serves to represent value, especially in indirect cases where the object of one's emotion is not perceptually present; the Nietzschean theory fares better, since it specifies a sui generis phenomenological component, essential to emotional experience, which represents value across cases (which is a plausible position for the view to take since is not committed to primacy of perceptual contact for emotional experience in the first place). Relatedly, perceptualist theories owe an account of how best to make sense of the fact that emotional experience essentially involves valenced components, whereas typical sense-perceptual experience does not - one does not

\footnotetext{
${ }^{42}$ See Poellner 2007: 235. Poellner 2012: 52-80 is more qualified, taking the relevant affective experiences as broadly akin to aesthetic experiences, which are analogous to sense-perceptions or involve quasi-sensory imaginings, and which 'represent value features of their intentional object' (2012: 67).

${ }^{43}$ See Döring 2007: 363-94 and Tappolet 2016: Ch.1.
} 
favour or disfavour anything, necessarily, when one sees a red and rectangular table. Again, the Nietzschean theory has a distinct line on this, insofar as it claims that there is a valenced component, essential to emotional experience, which is also intentional.

Given these considerations it is best to frame the Nietzschean view under consideration as a sui generis view, or at best a quasi-perceptual view which appeals to sui generis phenomenal-intentional components which are not present in paradigmatic perceptual experiences, and which are still present in emotional experiences whose content is not given in terms of a perceptually present object (e.g. emotions directed at the past). Importantly though, the Nietzschean view need not deny the correct claim that emotions often have perceptual, imaginative, cognitive, conative, and agential intentional bases, which provide the non-evaluative content that gets evaluatively qualified in emotional experience: for example, spilling my drink may precipitate embarrassment as a felt disfavour towards myself as having violated some social norm for culinary composure. Moreover, various mental states may follow the emotion, as consequents.

Finally, it is worth noting how the view provides solutions to the individuation and causal phenomenology problems. On the Nietzschean view part of the difference between fear, joy, anger, hatred, love, and so on, is that these emotions represent their particular objects as having different evaluative properties, through their respective felt valenced attitudes of favour and disfavour (attitude and content both contribute to individuation). Moreover, the Nietzschean view provides a solution to what makes an experience an emotional one at all by specifying the essential emotionality in terms of felt valenced attitudes towards evaluative properties, elucidating the difference between a sui generis emotional representation of value, and other forms of non-affective evaluative representation (potentially including non-emotional evaluative perceptions, if there are such mental states) ${ }^{44}$

\section{Conclusion}

\footnotetext{
${ }^{44}$ Note the resulting view bears some similarity to the attitudinal theory of emotions developed by Deonna and Teroni $(2012 ; 2017)$. However, theirs is a bodily-attitudinal view which denies that values figure at the level of the content of emotional experience. I save a detailed comparison of the views for a separate occasion.
} 
I have reconstructed a Nietzschean theory of emotion in terms of feelings towards value. While a full articulation of the view was beyond the scope of this article, I have shown why it is prima facie attractive. It provides one way of reconciling competing intuitions about emotional experiences, namely, that they are importantly connected to values and that their phenomenology is both distinctive and constitutive of their nature. Nevertheless, more could be said the important relation between emotion and motivation, and whether Nietzschean affects can be altered, and if so, to what extent. Moreover, there are complex questions which result from this view concerning the epistemology and metaphysics of value, and whether, in the former case, Nietzsche might countenance a positive epistemic role for some affects (the view of some affects as having evaluative content, and so correctness conditions, holds this open as a possibility). I signal these issues to highlight the developments needed for a comprehensive Nietzschean theory of emotions.

\section{Bibliography}

\section{Translations of Nietzsche's Works}

A The Anti-Christ, trans. J. Norman (Cambridge University Press, 2005)

BGE Beyond Good and Evil, trans. J. Norman (Cambridge University Press, 2002)

CW The Case of Wagner, trans. J, Norman (Cambridge University Press, 2005)

D Daybreak, trans. R. J. Hollingdale (Cambridge University Press (1997)

GM On the Genealogy of Morality, trans. C. Diethe (Cambridge University Press, 1997)

GS The Gay Science, trans. J. Nauckhoff (Cambridge University Press, 2001)

HA Human, All Too Human (Vol 1 and 2), trans. Hollingdale (Cambridge University Press, 1996)

KSA Werke: Kritische Gesamtausgabe, G. Colli, M. Montinari, et al. (eds). Berlin: de Gruyter, 1967-.

WLN Writings from the Late Notebooks, trans. K. Sturge (Cambridge University Press, 2003)

WP The Will to Power, trans. W. Kaufmann and R. J. Hollingdale (Vintage, 1967)

\section{Other works}


Barlassina, L., and Newen A. (2014) 'The Role of Bodily Perception in Emotion: In Defense of an Impure Somatic Theory' in Philosophy and Phenomenological Research 83 (3): 637-78.

Deonna, J. and Teroni, F. (2009) 'Taking affective explanations to heart' in Social Science Information 48 (3), 359-77.

— (2017) 'Getting Bodily Feelings into Emotional Experience in the Right Way' in Emotion Review 9 (1), $55-63$

Descartes, R. (1989) The Passions of the Soul, trans. S. H. Voss. Cambridge: Hacket Publishing.

Döring, S. (2007) 'Seeing What to Do: Affective Perception and Rational Motivation' in dialectica 61 (3), $363-94$.

Ekman, P. (1984) 'Expression and the Nature of Emotion' in K. R. Scherer and P. Ekman (eds) Approaches to Emotion, 319-44. New York: Psychology Press.

Goldie, P. (2000) The Emotions: A Philosophical Exploration. Oxford: Oxford University Press.

Hume, D. (1978) A Treatise of Human Nature, 2nd ed. Revised by P. H. Nidditch. Oxford: Oxford University Press.

James, W. (1884) 'What is an Emotion' in Mind 9 (34), 188-205.

Janaway, C. (2007) Beyond Selflessness: Reading Nietzsche's Genealogy. Oxford: Oxford University Press. Johnston, M. (2001) 'The Authority of Affect' in Philosophy and Phenomenological Research 63 (1), 181214.

Katsafanas, P. (2016) The Nietzschean Self: Moral Psychology, Agency, and the Unconscious. Oxford: Oxford University Press.

Lange, C. G. (1885) Om sindsbevaegelser: Et psyko-fysiologisk studie. Copenhagen: Jacob Lunds. Reprinted in C. G. Lange and W. James (Eds.), I. A. Haupt (trans.) The Emotions 1922. Baltimore: Williams and Wilkins.

Lazarus, R. S. (1991) Emotion and adaptation. New York: Oxford University Press.

Leiter, B. (2013) 'Moralities are a sign-language of the affects' in Social Philosophy and Policy 30 (1-2), 237-258.

- (2014) 'Review of C. Janaway and S. Robertson (eds) Nietzsche, Naturalism and Normativity' in Notre Dame Philosophical Review, 1-15.

— (2015) Nietzsche on Morality (second edition). London: Routledge. 
Lindquist, K., Wager, T. D., Kober, H., Bliss-Moreau, E., \& Barrett, L. F. (2012). 'The brain basis of emotion: A meta-analytic review' in Behavioral and Brain Sciences 35 (2), 121-143.

Lyons, W. (1980) Emotions. Cambridge: Cambridge University Press.

Marcel, A. J., and Lambie, J. A. (2002) 'Consciousness and the Varieties of Emotion Experience: A Theoretical Framework' in Psychological Review 109, 219-59.

Mendelovici, A. (2014) 'Pure Intentionalism about Moods and Emotions' in U. Kriegel (ed) Current Controversies in Philosophy of Mind, 135-57. London: Routledge.

Mitchell, J. (2018) 'The Intentionality and Intelligibility of Moods' in European Journal of Philosophy, 27 (1), 118-134.

Montague, M. (2009) 'The Logic, Intentionality, and Phenomenology of Emotion' in Philosophical Studies 145(2), 171-92.

Mulligan, K. (2007) 'Intentionality, Knowledge and Formal Objects' in Disputatio 2 (23), 1-24.

Nussbaum, C. N. (2001) Upheavals of Thought: The Intelligence of Emotions. Cambridge: Cambridge University Press.

Poellner, P. (2007) 'Affect, Value and Objectivity' in B. Leiter and N. Sinhababu (eds) Nietzsche and Morality, 227-61. Oxford: Oxford University Press.

— (2012) 'Aestheticist Ethics' in C. Janaway and S. Robertson (eds) Nietzsche, Naturalism and Normativity, 52-80. Oxford: Oxford University Press.

— (2016) 'Phenomenology and the Perceptual Model of Emotion' in Proceedings of the Aristotelian Society, Vol. CXVI, Part 3, 1-28.

Prinz, J. (2004) Gut Reactions: A Perceptual Theory of Emotion. Oxford: Oxford University Press.

— (2007) The Emotional Construction of Morals. Oxford: Oxford University Press.

Riccardi, M (2018) 'Nietzsche on the Superficiality of Consciousness' in M. Dries (ed.) in Nietzsche on Consciousness and the Embodied Mind. London: De Gruyter.

Ryle, G. (1990) The Concept of Mind. London: Penguin.

Stocker, M. (1983) 'Psychic feelings: Their importance and irreducibility' in Australasian Journal of Philosophy 61, 5-26.

- (2010) 'Intellectual and Other Nonstandard Emotions' in P. Goldie (ed) The Oxford Handbook of Philosophy of Emotion, 401-23. Oxford: Oxford University Press. 
A Nietzschean Theory of Emotion

Tappolet, C. (2016) Emotions, Values and Agency. Oxford: Oxford University Press.

Teroni, F. (2007) ‘Emotions and Formal Objects’ in dialectica 61 (3), 395-415.

Tye, M. (1995) Ten Problems of Consciousness. Cambridge: MIT Press. 